TAHKIM, Jurnal Peradaban dan Hukum Islam. Vol.1 No.2 (0ktober, 2018) | ISSN : $2597-7962$

\title{
LEGISLASI HUKUM EKONOMI SYARIAH: STUDI TENTANG PRODUK REGULASI HUKUM EKONOMI SYARIAH DI INDONESIA
}

\author{
Panji Adam \\ Fakultas Syariah Universitas Islam Bandung \\ panjiadam06@gmail.com
}

\begin{abstract}
ABSTRAK
Legislasi adalah proses yang berlangsung di lembaga legislatif, yakni pembuatan dan pengundangan peraturan perundang-undangan. Materi hukum Islam dapat menjadi muatan dalam proses legislasi melalui mekanisme positivisasi. Salah satu sub bidang dalam kajian hukum Islam adalah hukum ekonomi syariah. Hukum ekonomi syariah merupakan subsistem dalam sistem hukum Islam yang dari waktu ke waktu mengalami perkembangan yang cukup signifikan. Oleh karena itu perlu adanya positivisasi hukum melalui upaya legislasi hukum. Tujuan penelitian ini untuk mengetahui kedudukan hukum ekonomi syariah menurut konsep sistem hukum, dan produk regulasi hukum ekonomi syariah apa sajakah yang bersumber dari norma hukum Islam. Hasil penelitian menunjukan bahwa, komponen sistem hukum terdiri atas 3 unsur, yaitu struktur, substansi dan budaya hukum. Kedudukan hukum ekonomi syariah dalam ketiga sistem hukum tersebut sudah teraplikasikan. Hal ini dapat dilihat dari banyaknya lembaga-lembaga atau pranata-pranata ekonomi yang berbasiskan nilai-nilai syariah. Terdapat beberapa regulasi dibidang hukum ekonomi syariah yang telah dibuat oleh lembaga legislatif yang bersumber dari norma-norma hukum Islam. Produk-produk regulasi dibidang hukum ekonomi syariah yang bersumber dari noma-norma hukum Islam yaitu: UU No. 23/2011 tentang Pengelolaan Zakat; UU No. 41/2004 tentang Wakaf; UU No. 19/2008 tentang Surat berharga Syariah Negara; dan UU No. 21/2008 tentang Perbankan Syariah.
\end{abstract}

\section{Kata Kunci: Legislasi, Hukum Ekonomi Syariah, Regulasi}

\begin{abstract}
Legislation is the process that takes place in the legislature, namely the making and enactment of laws and regulations. Islamic legal material can be the content of the legislative process through the positivisation mechanism. One sub-field in the study of Islamic law is sharia economic law. Sharia economic law is a subsystem in the Islamic legal system that from time to time experiences significant development. Therefore, it is necessary to have legal positivisation through legal legislation efforts. The purpose of this study is to determine the position of Islamic economic law according to the concept of the legal system, and what products of regulation of Islamic economic law are derived from Islamic legal norms. The results of the study show that, the legal system component consists of 3 elements, namely structure, substance and legal culture. The position of Islamic economic law in the three legal systems has been applied. This can be seen from the number of economic institutions or institutions based on Islamic values. There are several regulations in the field of sharia economic law that have been made by the
\end{abstract}


TAHKIM, Jurnal Peradaban dan Hukum Islam. Vol.1 No.2 (0ktober, 2018) | ISSN : $2597-7962$

legislature which are derived from Islamic legal norms. Regulatory products in the field of Islamic economic law derived from Islamic legal norms are: Law No. 23/2011 concerning Management of Zakat; UU no. 41/2004 concerning Endowments; UU no. 19/2008 concerning State Sharia Securities; and Law No. 21/2008 concerning Islamic Banking.

\section{Keyword: Legislation, Sharia Economic Law, Regulation}

\section{A. PENDAHULUAN}

Hukum merupakan pedoman yang legitimate bagi kehidupan politik dalam mengambil keputusan dan tindakan-tindakan sebagai kerangka untuk rekayasa sosial secara tertib. ${ }^{1}$ Maurice Duverger menyatakan bahwa hukum ditentukan oleh kekuasaan politik; dia terdiri dari tubuh undang-undang dan prosedur yang dibuat atau diakui oleh kekuasaan politik. ${ }^{2}$ Mengingat konstitusi merupakan kaidah hukum pertama, maka dalam pembentukannya digunakan cara sosiologis, ${ }^{3}$ sebab suatu sistem konstitusi hanya mengasumsikan ditegakannya prinsip-prinsip tertentu, tetapi tidak bisa otomatis mewujudkan prinsip-prinsip tersebut.

Melihat dari keragaman agama, suku, etnis dan ras yang ada di Indonesia, maka salah satu yang menjadi fokus kajian bidang hukum adalah hukum agama mayoritas yang danut oleh rakyat Indonesia, yaitu Islam. Inilah yang dimaksud Van Apeldroon sebagaimana dikutip oleh Sudarsono, bahwa hukum sesungguhnya berbeda antara satu tempat dengan tempat lainnya. Ia berkaitan erat dengan unsur-unsur yang ada di dalamnya, yaitu manusia, alam, tradisi, akal dan budinya. Hukum melekat pada masyarakat dan hidup bersama-sama dengan masyarakat manusia, ia adalah perbendaharaan kebudayaan manusia. ${ }^{4}$

Studi politik hukum Islam di Indonesia sama artinya memperbincangkan kepentingan mayoritas masyarakat Indonesia yang nota-benenya adalah masyarakat muslim. Studi politik hukum Islam intinya menyangkut kepentingan hukum sebagian besar rakyat Indonesia. ${ }^{5}$ Studi ini lebih memfokuskan pada kondisi objek hukum Islam

\footnotetext{
${ }^{1}$ Sirajuddin, Legislasi Hukum Islam di Indonesia (Yogyakarta: Pustaka Pelajar, 2008), hlm. 1.

${ }^{2}$ Maurice Duverger, Sosiologi Politik (Jakarta: Gama Media, 1981), hlm. 258.

3 Taufiqurrahman Syahuri, Hukum Konstitusi: Proses dan Prosedur Perubahan UUD di Indonesia 1945-2002 (Bogor: Ghalia Indonesia, 2010), hlm. 43.

${ }^{4}$ Sudarsono, Pengantar Ilmu Hukum (Jakarta: Rineka Cipta, 2004), hlm. 167.

${ }^{5}$ Abdul Halim, Politik Hukum Islam di Indonesia (Jakarta: Ciputat Press, 2005), hlm. 4-5.
} 
TAHKIM, Jurnal Peradaban dan Hukum Islam. Vol.1 No.2 (0ktober, 2018) | ISSN : $2597-7962$

dalam politik hukum di Indonesia, perdebatan, serta produk hukum yang pernah dilahirkan.

Legislasi adalah proses yang berlangsung di lembaga legislatif, yakni pembuatan dan pengundangan peraturan perundang-undangan. Materi hukum Islam dapat menjadi muatan dalam proses legislasi melalui mekanisme positivisasi. Positivisasi hukum Islam dalam pembangunan hukum nasional memiliki 2 (dua) bentuk, yaitu: pertama, hukum Islam tidak bisa diberlakukan dalam lingkup nasional karena kondisi pluralitas bangsa Indonesia, namun hukum Islam dapat menjadi salah satu sumber nilai dalam penyusunan hukum nasional. Kedua, hukum Islam dapat menjadi hukum positif yang berlaku bagi semua warga melalui proses legislasi yang sah seperti bidang muamalah atau hukum ekonomi syariah. ${ }^{6}$

Positivisasi hukum Islam memiliki prospek yang cerah karena era reformasi yang demokratis memiliki karakter hukum responsif. Sisrem hukum Barat/Kolonial sudah tidak berkembang, jumlah penduduk mayoritas beragama Islam, politik pemerintah yang mendukung berkembangnya hukum Islam, dan hukum Islam menjadi salah satu sumber bahan baku dalam pembentukan hukum nasional di samping hukum adat dan hukum Barat/kolonial. $^{7}$

Kajian tentang legislasi hukum Islam dalam konteks sistem hukum suatu negara selalu memunculkan 2 (dua) wajah hukum Islam itu sendiri, yaitu wajah universal dan wajah partikular. ${ }^{8}$ Hukum Islam memiliki wajah universal dalam pengertiannya sebagai syariat Islam yang bersumber dari al-Quran dan hadis Nabi Muhammad Saw. Sebagai ketentuan yang bersumber dari al-Quran dan hadis, hukum Islam melampaui batas ruang dan waktu. Hukum Islam akan menampakan wajah yang sama dan serupa di berbagai belahan dunia manapun dan dalam kurun waktu kapanpun. Sementara itu, partikularitas hukum Islam segera muncul ketika ia dijaki berbagai aspek dan ciri-ciri khususnya di

\footnotetext{
${ }^{6}$ Khotubul Umam, Legislasi Fikih Ekonomi dan Penerapannya dalam Produk Perbankan Syariah di Indonesia (Yogyakarta: BPFE, 2011), hlm. 29.

${ }^{7}$ Ibid., hlm. 29.

${ }^{8}$ Abdurahman, Kompilasi Hukum Islam di Indonesia (Jakarta: Akademika Presindo, 2007), hlm. 4.
} 
setiap negara muslim, misalnya penerapan hukum Islam di Indonesia yang memiliki sistem, substansi, dan format yang khas. ${ }^{9}$

Menurut Jeje Zaenudin, terdapat 3 (tiga) pertimbangan utama tentang urgensi legislasi hukum Islam di Indonesia. Pertama, umat Islam di Indonesia tidak hanya menjadi penduduk mayoritas di Indonesia tetapi juga di dunia. Oleh karena itu, penerapan hukum Islam di Indonesia tidak hanya memberikan penghargaan kepada penduduk mayoritas ini, tetapi juga mampu menjadi barometer penegakan hukum Islam bagi negara muslim lainnya. Kedua, Pencasila, sebagai dasar negara, telah memberikan ruang terbuka bagi pelaksanaan hukum Islam bagi pemeluknya. Ketiga, program pembangunan nasional salah satunya diarahkan kepada agenda pembangunan hukum nasional. Agenda pembangunan hukum nasional ini membuka peluang besar bagi penyerapan normanorma hukum Islam sekaligus sebagai upaya transformasi norma-norma hukum Islam ke dalam produk perundang-undangan negara. Sebab agenda pembangunan hukum nasional sendiri, dalam hal ini proses legislasi undang-undang mengambil bahan baku dari normanorma hukum Barat (internasional, hukum adat dan hukum Islam. Dimensi ketuhanan (ilahiyah) dan dimensi kemanusiaan (insanyah) yang dimiliki hukum Islam membuatnya sesuai dengan agenda pembangunan hukum nasional tersebut di atas. ${ }^{10}$

Hukum ekonomi syariah merupakan subsistem dalam sistem hukum Islam yang dari waktu ke waktu mengalami perkembangan yang cukup signifikan. Hukum ekonomi syariah adalah segala norma atau ketentuan hukum terkait dengan ekonomi syariah. Adapun ekonomi syariah adalah konsep dan praktik ekonomi yang didasarkan pada prinsip-prinsip syariah. ${ }^{11}$ Istilah syariah bersumber dan tercantum dalam al-Quran. Istilah syariah memiliki arti aturan hukum yang jelas, tegas dan harus diikuti. Ketika kata ekonomi disintesakan dan diintegralkan dengan kata syariah menjadi ekonomi syariah, memiliki makna aktivitas teoritis dan praktik di sektor ekonomi yang dilakukan dengan mengacu pada aturan hukum yang jelas, tegas dan harus diikuti. Keberlakuan ekonomi

9 Jeje Zaenudin, Metode Dan Strategi Penerapan Syariat Islam di Indonesia: Memahami Gradualitas Penerapan Syariat di Indonesia Menuju Penerapan Islam Secara Kaffah (Jakarta: MIUMI dengan Pembela Islam Media, 2015), hlm. 1-2.

${ }^{10}$ Ibid., hlm. 3-4.

${ }^{11}$ Menurut Pasal 1 angka (12) Undang-Undang Nomor 21 Tahun 2008 tentang Perbankan Syariah, Prinsip Syariah adalah prinsip hukum Islam dalam kegiatan perbankan berdasarkan fatwa yang dikeluarkan oleh lembaga yang memiliki kewenangan dalam penetapan fatwa di bidang syariah. 
syariah di tengah kehidupan berbangsa dan bernegara tidak lepas dari aspek politik, hukum, dan politik hukum di Indonesia. ${ }^{12}$

Hukum ekonomi syariah sebagai salah satu penyangga kekuatan peradaban Indonesia terus berkembang pesat. Ada 3 (tiga) elemen penting yang menjadi penyangga bangunan hukum ekonomi syariah, yaitu peraturan hukum yang valid dan komprehensif (legal substance), aparatur pelaksana hukum yang adil dan berwibawa serta sarana dan prasarana hukum yang memadai (legal structure), serta kesadaran dan kepatuhan hukum masyarakat yang total dan maksimal (legal culture). ${ }^{13}$

\section{B. PEMBAHASAN}

\section{Kedudukan Hukum Ekonomi Syariah Menurut Konsep Sistem Hukum}

Sistem hukum (legal system) menurut bahasa adalah satu kesatuan hukum yang tersusun dari tiga unsur, yaitu: (1) Struktur; (2) Substansi; (3) Kultur Hukum ${ }^{14}$, jika berbicara tentang "sistem hukum", maka ketiga unsur tersebut yang menjadi fokus pembahasannya, Struktur adalah keseluruhan institusi penegakan hukum, beserta aparatnya yang mencakup: kepolisian dengan para polisinya, kejaksaan dengan para jaksanya, kantor-kantor pengacara dengan para pengacaranya, dan pengadilan dengan para hakimnya. Substansi adalah keseluruhan asas hukum, norma hukum dan aturan hukum, baik yang tertulis maupun yang tidak tertulis, termasuk putusan pengadilan. Kultur hukum adalah kebiasaan-kebiasaan, opini-opini, cara berpikir dan cara bertindak, baik dari para penegak hukum maupun dari warga masyarakat. ${ }^{15}$

Menurut Lawrance M. Friedman sebagaimana dikutip oleh Agus Brotosusilo, suatu sistem hukum dapat dibagi ke dalam 3 (tiga) bagian atau komponen, yaitu: ${ }^{16}$ (1) Komponen Struktural; (2) Komponen Substansi; (3) Komponen Budaya Hukum.

Adapun kedudukan hukum ekonomi syariah dalam sistem hukum sesuai dengan komponen di atas adalah sebagai berikut:

${ }^{12}$ Mohamad Nur Yasin, Politik Hukum Ekonomi Syariah Di Indonesia (Malang: UIN Maliki Press, 2018), hlm. 2.

13 Ibid., hlm. 4.

14 Juhaya S Praja, Teori Hukum dan Aplikasinya (Bandung: Pustaka Setia, 2011), hlm. 55. hlm. 51 .

15 Neni Sri Imaniyati dan Panji Adam, Pengantar Hukum Indonesia (Jakarta: Sinar Grafika, 2018),

${ }^{16}$ Agus Brotosusilo, Sistem Hukum Indonesia (Jakarta: Universitas Terbuka, 1986), hlm. 5. 


\section{a. Struktur Hukum}

Struktur hukum merupakan aspek penting dalam perumusan, pemberlakuan, dan penegakan hukum. Ada 2 (dua) aspek penting dalam struktur hukum yang harus interkomplementer dan tidak boleh saling menegasikan. Pertama, sarana dan prasarana hukum, yaitu segala fasilitas yang lengkap dan up to date baik langsung atau tidak langsung yang diperlukan untuk perumusan, pemberlakuan, dan penegakan hukum; kedua, aparat hukum yang berwibawa, meluputi aparat perumus hukum, pelaksana hukum, dan penegak hukum.

Aspek pertama yaitu sarana dan prasarana dalam hukum ekonomi syariah meliputi lembaga yang bergerak dalam bidang ekonomi syariah, baik dalam skala makro maupun skala mikro. Dalam konteks ekonomi syariah terdapat 2 (dua) lembaga yang berperan penting demi terlaksananya sistem ini, yaitu lembaga keuangan bank, seperti Bank Syariah, baik yang berbentuk BUS (Bank Umum Syariah), UUS (Unit Usaha Syariah) dan BPRS (Bank Pembiayaan Syariah), ataupun lembaga keuangan bukan bank meliputi seperti Asuransi Syariah, Pasar Modal Syariah, Pegadaian Syariah, Modal Ventura Syariah, bahkan yang berskala mikro seperti Koperasi Syariah/BMT (Baitul Mal wat Tamwil) atau yang lainnya.

Seiring dengan perkembangan dunia bisnis, terdapat lembaga-lembaga bisnis yang menggunakan prinsip syariah sebagai bagian dari sarana dan prasarana dalam hukum ekonomi syariah seperti lembaga-lembaga pariwisata syariah yang meliputi hotel syariah, rumah makan syariah, dan lain sebagainya. Selain itu, juga terdapat rumah sakit yang beroperasi sesuai dengan prinsip syariah. Lembaga-lembaga tersebut memiliki payung hukum berupa fatwa yang dikeluarkan oleh lembaga yang memliki otoritas dalam pembentukan fatwa di bidang ekonomi syariah di Indonesia, yaitu Dewan Syariah Nasional-Majelis Ulama Indonesia atau biasa disebut dengan DSN-MUI.

Aspek kedua, yaitu aparat hukum yang berwibawa, meluputi aparat perumus hukum, pelaksana hukum, dan penegak hukum. Dalam koteks hukum ekonomi syariah, legislatif merupakan aparat penegak hukum, karena dalam bidang ekonomi syariah telah lahir produk-produk hukum ekonomi syariah yang telah berbentuk peraturan perundangundangan. Selain legislatif, dalam perumusan dasar-dasar payung hukum dibidang ekonomi syariah, Majelis Ulama Indonesia memiliki peran penting sebagaimana 
TAHKIM, Jurnal Peradaban dan Hukum Islam. Vol.1 No.2 (0ktober, 2018) | ISSN : $2597-7962$

diamanatkan dalam Pasal 1 angka 12 Undang-Undang Nomor 21 Tahun 2008 tentang Perbankan Syariah. Peran MUI dalam bidang ekonomi syariah, yaitu Dewan Syariah Nasional (DSN-MUI) memiliki otoritas dalam merumuskan serta mengeluarkan fatwafatwa dibidang ekonomi syariah, ${ }^{17}$ dan sampai tahun 2018 DSN-MUI telah mengeluarkan fatwa dibidang ekomoni syariah sebanyak 121 fatwa.

Selain lembaga-lembaga sarana dan prasarana baik berupa lembaga keuangan bank ataupun lembaga keuangan bukan bank atau lembaga bisnis-bisnis yang berbasis syariah, dalam konteks hukum ekonomi syariah terdapat lembaga pelaksana hukum seperti Bank Indonesia. Bank Indonesia ${ }^{18}$ sebagai bank sentral memiliki kedudukan dalam hal pelaksanaan hukum ekonomi syariah di Indonesia. Selain Bank Indonesia, terdapat lembaga berikutnya yang menjadi pelaksana hukum ekonomi syariah, yaitu Otoritas Jasa Keuangan Indonesia.

Aspek penegak hukum dalam konteks hukum ekonomi syariah adalah lembagalembaga yang berfungsi untuk menengakan hukum seperti lembaga peradilan atau lembaga-lembaga penyelesaian sengketa di bidang ekonomi syariah. Pasca diundangkannya Undang-Undang Nomor 3 Tahun 2006 tentang Perubahan Atas UndangUndang Nomor 7 Tahun 1989 tentang Peadilan Agama, khususnya Pasal 49 mengatur mengenai perluasan kewenangan peradilan agama, yang mana lembaga peradilan agama ini mempnyai kewenangan absolut untuk menyelesaikan perkara di bidang sengketa ekonomi syariah. Selain lembaga litigasi, lembaga non litigasi pun ikut hadir eksistensinya sebagai lembaga yang berfungsi untuk menyelesaikan sengketa ekonomi syariah. Lembaga-lembaga litigasi tersebut seperti lembaga mediasi, lembaga arbitrase (khusus dalam sengketa ekonomi syariah) maka lembaga ini dikenal dengan sebutan Basyarnas (Badan Arbitrase Syariah Nasional) yang berada di bawah Majelis Ulama Indonesia. $^{19}$

\footnotetext{
${ }^{17}$ Panji Adam, Fatwa-Fatwa Ekonomi Syariah: Konsep, Metodologi Dan Implementasinya Pada Lembaga Keuangan Syariah (Jakarta: Amzah, 2018), hlm. 164-165.

${ }_{18}$ Neni Sri Imaniyati dan Panji Adam, Pengantar Hukum Perbankan Indonesia (Bandung: Refika Aditama, 2016), hlm. 73.

${ }^{19}$ Neni Sri Imaniyati dan Panji Adam, Hukum Bisnis: Dilengkapi Dengan Kajian Hukum Bisnis Syariah (Bandung: Refika Aditama, 2017), hlm. 376.
} 


\section{b. Substansi Hukum}

Hukum dalam hal ini adalah peraturan yang dibuat oleh pejabat yang berwenang untuk mengatur ketertiban masyarakat dan bagi siapa yang nelanggar mendapatkan sanksi. Hukum yang berlaku di Indonesia mengikuti paham positivistik, tepatnya positivisme hukum (legal positivism) yang berprinsip bahwa hukum adalah apa yang tertulis di dalam perundang-undangan negara (law is what is written on the book). ${ }^{20}$

Dalam konteks teori gelding, setidaknya peraturan perundang-undangan yang dibuat harus memenuhi unsur-unsur sebagai berikut: ${ }^{21}$

Pertama, aspek filosofis. Hukum harus dibuat dengan mengakomodasi nilai agung yang menjadi filosofi atau jiwa kehidupan masyarakat. Dasar bernegara bagi bangsa Indonesia adalah Pancasila yang digali dar nilai moral bangsa. Materi hukum yang bertentangan dengan nilai moral dan prinsip hidup yang dupegangi masyarakat akan menjadikan hukum tumpul dan tidak bisa menjadi acuan tatanan sosial dan hidup bernagara.

Kedua, aspek sosiologis. Hukum harus disusun dengan mengakomodasi potensi dan nilai-nilai yang hidup di tengah masyarakat. Setiap komunitas selalu memiliki pembeda dan keunggulan masing-masing (local wisdom) yang menjadi bencmarking dan identitas pembeda (distinction) dengan masyarakat lainnya. Hukum yang berpespektif sosiologis harus tersublimasi oleh prinsip-prinsip yang menyatukan berbagai local wisdom, sehingga semua nilai-nilai local wisdom terwadai dalam substansi hukum. Hukum yang ahistoris dengan realitas sosial tidak akan pernah mendapat dukungan masyarakat, sebalknya justru memiliki resistensi tinggi dan potensial selalu ditentang oleh masyarakat.

Ketiga, aspek yuridis. Hukum yang shahih adalah hukm yang ditandai oleh tidak adanya peraturan yang mengandung pertentangan antara satu dan yang lain baik selevel maupun dengan peraturan yang lebih tinggi. Setap peraturan perundang-undangan di Indonesia diidealkan selalu sinkron dengan peraturan di atasnya. Peraturan yang bertolakbelakang dengan peaturan yang lebih tinggi selalu memunculkan pertentangan

\footnotetext{
${ }^{20}$ Mohamad Nur Yasin..., hlm. 169.

${ }^{21}$ Ibid., hlm. 169-170.
} 
hukum (conflict of norm) atau minimal kekaburan hukum (vague of norm) dan menyebabkan kebingungan serta ketidaktertiban sosial ekonomi politik masyarakat.

Dalam konteks hukum di Indonesia, telah banyak regulasi dalam bentuk peraturan perundang-undangan yang bernuansa hukum Islam lebih khusus mengenai hukum ekonomi syariah. Pembahasan lebih lanjut mengenai produk-produk legislasi di bidang hukum ekonomi syariah akan dibahan pada sub bab berikutnya.

\section{c. Budaya Hukum}

Salah satu pilar penting sistem hukum adalah kesadaran hukum. Kesadaran hukum bisa dimaknai sebagai keyakinan terhadap nilai-nilai yang terdapat di dalam diri manusia tentang hukum yang pernah ada, yang ada dan yang akan ada. Dalam situasi yang konkret, kesadaran hukum menjelma dalam bentuk kepatuhan atau ketaatan kepada hukum. ${ }^{22}$ Kepatuhan yang berlangsung secara terus menerus melahirkan dan menginspirasi kehendak positif berupa kebudayaan hukum. Budaya hukum adalah hasil cipta karsa masyarakat berkaitan dengan hukum. Cipta dan karsa mencakup nilai hukum, asas hukum, norma hukum, dan perbuatan hukum yang hidup dan terpraktekan di tenagh kehidupan masyarakat. ${ }^{23}$

Mayoritas masyarakat Indonesia adalah muslim. Nilai hukum yang dimaksud adalah nilai Islam yang termaktub dalam al-Quran dan Sunnah Saw. Dalam konteks hukum ekonomi syariah, budaya hukum ini tercerminkan dalam kepatuhan terhadap nilainilai serta norma-norma syariah, sehingga dalam melakukan aktivitas ekonomi tercerminkan kepatuhan terhadap prinsip-prinsip syariah.

\section{Teori Legislasi dalam Hukum Islam}

Dalam kajian politik hukum Islam, terdapat 3 (tiga) istilah penting yang memiliki hubungan makna dengan politik hukum Islam, yaitu (1) ilmu taqnin al-ahkam; (1) ilmu tathbiq al-ahkam; (3) ilmu taghyir al-ahkam. Taqnin al-Ahkam adalah ilmu yang membahas teori-teori legislasi hukum Islam dan penerimaannya sebagai sumber otoritatif dalam tata hukum suatu negara. Tathbiq al-Ahkam adalah ilmu yang membahas tata atur penerapan hukum Islam setelah dilegislasi, diterima sebagai sumber otoritatif, dan

${ }^{22}$ Muhamad Edwin, Filsafat Hukum, refleksi Kritis Terhadap Hukum (Jakarta: PT RajaGrafindo Persada, 2012), hlm. 135.

${ }^{23}$ Mohamad Nur Yasin..., hlm. 172. 
tertuang dalam bentuk qanun. Adapun taghyir al-Ahkam adalah ilmu yang membahas perubahan (amandemen) atas hukum yang telah dijalankan, tetapi dinilai tidak memenuhi aspek-aspek keadilan dan kemaslahatan (kepentingan) publik. ${ }^{24}$

Ilmu Taqnin al-Ahkam memetakan 3 (tiga) tugas negara berkaitan dengan hukum, yaitu membentuk (taqnin), menrapkan (tathbiq), dan mengubah (taghyir). Membentuk hukum (taqnin) merupakan tindakan politis, menerapkan hukum merupakan tindakan yuridis, sedangkan mengubah hukum merupakan gabungan dari tindakan politis dan tindakan yuridis. ${ }^{25}$

Pembentukan hukum (taqnin) memiliki hubungan dengan rangkaian politik yang di dalamnya terdapat pirantu dan mekanisme politik. Salah satu mekanisme politik dalam merumuskan hukum Islam adalah ijma'. Ijma' atau konsensus merupakan piranti politik yang setara dengan mekanisme voting dalam politik modern. Ijma' bukan kesepakatan bulat, melainkan proses mencari pandangan mayoritas yang sama dari sekian pandangan yang berbeda dan masih menyisakan pandangan alternatif. Mekanisme lain yang ditempuh dalam pembentukan hukum (taqnin) adalah ittifaq, yaitu kesepakatan bulat dalam bentuk akumulasi tanpa menyisakan pandangan alternatif. ${ }^{26}$

Secara etimologis, kata taqnîn merupakan bentuk masdar dari qannana, yang berarti membentuk undang-undang. Ada yang berpendapat kata ini merupakan serapan dari Bahasa Romawi, canon. Namun ada juga yang berpendapat, kata ini berasal dari Bahasa Persia. Seakar dengan taqnin adalah kata qanun yang berarti ukuran segala sesuatu, dan juga berarti jalan atau cara (thariqah). ${ }^{27}$

Qanun al-Ahkam berarti mengumpulkan hukum dan kaidah penetapan hukum (tasyri`) yang berkaitan dengan masalah hubungan sosial, menyusunnya secara sistematis, serta mengungkapkannya dengan kalimat-kalimat yang tegas, ringkas, dan jelas dalam bentuk bab, pasal, dan atau ayat yang memiliki nomor secara berurutan, kemudian menetapkannya sebagai undangundang atau peraturan, lantas disahkan oleh

\footnotetext{
${ }^{24}$ Ija Suntana, Politik Hukum Islam, (Bandung: Pustaka Setia 2014), hlm. 1.

${ }^{25}$ Ibid., hlm. 2.

${ }^{26}$ Ibid.

${ }^{27}$ Ibrahim Anis, Al-Mu jam al-Wasîth, Juz II, (Beirut: Dar al-Ilmiyah, 1987), hlm. 763.
} 
TAHKIM, Jurnal Peradaban dan Hukum Islam. Vol.1 No.2 (0ktober, 2018) | ISSN : $2597-7962$

pemerintah, sehingga wajib bagi para penegak hukum menerapkannya di tengah masyarakat. $^{28}$

Dengan demikian, Taqnin al-Ahkam berarti mengumpulkan hukum dan kaidah penetapan hukum yang berkaitan dengan masalah hubungan sosial, menyusunnya secara sistematis, serta mengungkapkannya dengan kalimat-kalimat yang tegas, ringkas, dan jelas dalam bentuk bab, pasal, dan atau ayat yang memiliki nomor secara berurutan, kemudian menetapkannya sebagai undang-undang atau peraturan, lantas disahkan oleh pemerintah, sehingga wajib para penegak hukum menerapkannya di tengah masyarakat. ${ }^{29}$

\section{Produk Regulasi Hukum Ekonomi Syariah yang Bersumber dari Norma}

\section{Hukum Islam}

Sebagian hukum Islam dalam dimensi peraturan perundang-undangan telah terintegrasu dalam hukum nasional dalam perspektif hukum yang telah dilegislasi, salah satunya adalah aturan-aturan di bidang hukum ekonomi syariah. Pada sub bab ini akan dikemukakan beberapa produk hukum/regulasi hukum ekonomi syariah yang bersumber dari norma hukum Islam.

\section{a. Undang-Undang Nomor 23 Tahun 2011 tentang Pengelolaan Zakat}

Pembukaan Undang-Undang Dasar 1945 mengamanatkan bahwa memajukan kesejahteraan umum merupakan salah satu tujuan nasional negara Republik Indonesia. Untuk mewujudkan tujuan nasional tersebut, maka bangsa Indonesia harus senantiasa melaksanakan pembangunan, baik yang bersifat fisik, material, mental, maupun spiritual, antara lain melalui pembangunan di bidang agama yang mencakup terciptahnya suasana kehidupan beragama yang penuh keimanan dan ketakwaan terhadap Ketuhanan Yang Maha Esa, meningkatnya akhlak mulia, terwujudnya kemakmuran hidup umat beragama yang dinamis sebagai landasan persatuan dan kesatuan bagngsa, dan meningkatnya peran serta masyarakat dalam pembangunan nasional. ${ }^{30}$

Guna mencapai tujuan tersebut, perlu dilakukan berbagai upaya, antara lain dengan menggali dan memanfaatkan dana melalui zakat. Zakat sebagai rukun Islam merupakan kewajiban setiap muslim yang mampu untuk membayarnya dan diperuntukan

${ }^{28}$ Mushtafa aL-Zarqa, Al-Madkhal al-Fiqh al- `Am, juz 1 (Beirut: Dar al-Qalam, 1418 H), hlm. 313.

${ }^{29}$ Ibid. .

${ }^{30}$ Warkum Sumitro, Legislasi Hukum Islam Tramsformatif: Reformulasi Konsep Formulasi Syariah dalam Legislasi Hukum Islam di Indonesia (Malang: Setara Press, 2015), hlm. 80. 
TAHKIM, Jurnal Peradaban dan Hukum Islam. Vol.1 No.2 (0ktober, 2018) | ISSN : $2597-7962$

bagi mereka yang berhak menerimanya. Dengan pengelolaan yang baik zakat merupakan sumber dana potensial yang dapat dimanfaatkan untuk memajukan kesejahteraan umum bagi seluruh masyarakat. ${ }^{31}$

Undang-Undang Nomor 23 Tahun 2011 tentang Pengelolaan Zakat dsahkan dan diundnagkan di Jakarta pada tanggal 25 November 2011 (Lembaran Negara Republik Indonesia Tahun 2011 Nomor 115, tambahan Lembaran Negara Republik Indonesia Nomor 5255). Undang-Undang yang lahir pada 27 Oktober 2011 ini meurpakan amandeman dari undang-undang sebelumnya, yakni Undang-Undang Nomor 38 Tahun 1999.

Undang-undang Nomor 23 Tahun 2011 tentang Pengalolaan Zakat terdiri dari 11 Bab dan 47 Pasal. Secara global isinya sebagai berikut. Bab I Ketentuan Umum (Pasal 14), Bab II Badan Amil Zakat Nasional (Pasal 5-20), Bab III Kekuasaan Pengumpulan, Pendistribusian, Pendayagunaan dan pelaporan (Pasal 21-29), Bab IV Pembiayaan (Pasal 30-33), Bab V Pembinaan dan Pengawasan (Pasal 34), Bab VI Peran Serta Masyarakat (Pasal 35), Bab VII Sanksi Administrasi (Pasal 36), Bab VIII Larangan (Pasal 37-38), Bab IX Ketentuan Pidana (Pasal 39-42), Bab X Ketentuan Peralihan (Pasal 43), Bab XI Ketentuan Penutup (Pasal 44-47).

Dalam Undang-Undang Nomor 23 Tahun 2011 tentang Pengelolaan Zakat, terdapat aturan mengenai zakat dapat mengurangi pajak pengahasilan. Zakat sebagai mengurangi pajak, terdapat dalam Pasal 22 UU No. 23 Tahun 2011 tentang Pengelolaan Zakat. Bunyi pasal tersebut adalah sebagai berikut: "Zakat yang dibayarkan oleh muzaki kepada BAZNAS atau LAZ dapat dikurangi dari penghasilan karena pajak”.

Yang dimaksud dengan pajak penghasilan menurut UU No. 7 Tahun 1983 sebagaimana telah diubah terakhir dengan UU No. 17 Tahun 2000 tentang Pajak. Penghasilan adalah pajak yang dikenakan terhadap subjek pajak atas penghasilan yang diterima atau diperoleh dalam tahun pajak.

Yang dimaksud dengan muzaki dapat berbentuk pribadi atau badan hukum. Hal ini terdapat dalam Pasal 1 angka (5) UU No. 23 Tahun 2011 tentang Pengelolaan Zakat. Muzaki adalah seornag Muslim atau badan usaha yang berkewajiban menunaikan zakat.

\footnotetext{
${ }^{31}$ Ibid.
} 
Keterkaitan antara zakat dan pajak dapat dilihat dari definisi zakat dan pajak. Menurut UU No. 23 Tahun 2011 tentang Pengelolaan Zakat, zakat adalah harta yang wajib dikeluarkan oleh seorang Muslim atau badan usaha untuk diberikan kepada yang berhak menerimanya sesuai dengan syariat Islam. ${ }^{32}$ Sedangkan pajak adalah iuran negara yang dapat dipaksakan yang terutang wajib membayarnya menurut peraturan dengan tidak mendapatkan prestasi kembali yang langsung dapat ditunjuk dan gunanya adalah untuk membiayai pengelolaan pengeluaran umum yang berhubungan dengan tugas negara dalam menjalankan pemerintahan.

Berdasarkan definisi tersebut, maka keterkaitan antara zakat dan pajak adalah sama-sama berfungsi sebagai sarana (ibadah-penunaian kewajiban-agama/negara) untuk mendistribusikan kembali penghasilan masyarakat yang mampu kepada masyarakat yang kurang mampu.

\section{b. Undang-Undang Nomor 41 Tahun 2004 tentang Wakaf}

Tujuan negara Republik Indonesia sebagaimana yang telah diamanatkan dalam Pembukaan Undang-Undang Dasar 1945 antara lain adalah memajukan kesejahteraan umum. Untuk mencapai tujuan tersebut, perlu digali dan dikembangkan potensi yang terdapat dalam pranata keagamaan yang memiliki manfaat ekonomis.

Salah satu langkah strategis untuk meningkatkan kesejahteraan umum, perlu meningkatkan peran wakaf sebagai pranata keagamaan yang tidak hanya bertujuan menyediakan berbagai sarana ibadan dan sosial, tetapi juga memiliki kekuatan ekonomi yang berpotensi, antara lain untuk memajukan kesejahtaraan umum, sehingga perlu dikembangkan pemanfaatannya sesuai dengan prinsip syariah. ${ }^{33}$

Pengelolaan wakaf sebagai salah satu aset yang terdapat dalam kalangan umat Islam harus dilakukan secara profesional dan bertanggung jawab di mata hukum. Semangat pemberdayaan wakaf, khususnya di Indonesua sesungguhnya mulai muncul, berkembang dan melibatkan seluruh potensi keumatan dengan dukungan penuh seperti lahirnya Undang-Undang Otonomi Daerah, Undang-Undang perpajakan dan UndangUndang Nomor 41 Tahun 2004 tentang Wakaf. Regulasi undang-undang perwakafan

\footnotetext{
${ }^{32}$ Pasal 1 angka (1) UU No. 23 Tahun 2011 tentang Pengelolaan Zakat.

${ }^{33}$ Warkum Sumitro, Legislasi Hukum Islam Tramsformatif..., hlm. 89.
} 
TAHKIM, Jurnal Peradaban dan Hukum Islam. Vol.1 No.2 (0ktober, 2018) | ISSN : $2597-7962$

sejatinya diperlukan demi memaksimalkan pengelolaan harta wakaf demi tercapainya kesejahteraan umum.

Kelahiran Undang-Undang Nomor 41 Tahun 2004 tentang Wakaf menjadi angin segar bagi umat Islam dalam hal perwakafan. Undang-undang Nomor 41 Tahun 2004 tentang Wakaf sebagai produk hukum nasional yang bersumber dari hukum Islam mengandung beberapa aspek: ${ }^{34}$

1) Bab II Pasal (2) menyatakan dengan tegas bahwa wakaf akan dianggap sah di mata hukum bilamana perlaksanaanya sesuai dengan syarah Islam. Ini berarti bahwa hukum Islam sudah menjadi baian yang integral dan terunifikasi dalam hukum nasional.

2) Benda yang diwakafkan (mauquf bih), dalam undang-undnag tersebut adalah benda wakaf yang diperluas tidak hanya pada benda tidak bergerak melainkan juga benda bergerak, seperti uang (cash waqf), saham, surat berharga, dan lainnya (Pasal 16 ayat (3)). Pembagian harta benda wakaf ini sesungguhnya merupakan salah satu bentuk ijtihad yang dilakukan oleh ulama Indonesia terhadap persoalan muamalah. Pernyataan ini didukung oleh Majelis Ulama Indonesia (MUI) dengan fatwanya tentang wakaf uang yang memutuskan bahwa wakaf uang hukumnya adalah jaiz (boleh) meskipun persyaratan yang diberikan oleh Komisi Fatwa Majelis Ulama Indonesia adalah uang yang diwakafkan tersebut harus diperuntukan bagi sehala sesuatu yang sesuai dengan ajaran Islam. ${ }^{35}$

3) Persyaratan nazir (pengelola harta wakaf) dalam PP Nomor 28 Tahun 1977 sebelumnya bersifat normatif sebagaimana tampak secara detail dalam undang-undnag wakaf yang baru ditambah dengan pengelolaan harta wakaf ditinjau dari aspek penyaluran seperti Pasal 22 ayat (1), (2) dan (3).

4) Konsekuensi huku bagi penyimpangan dalam pengelolaan harta benda wakaf juga diatur dalam Undang-Undang Nomor 41 Tahun 2004 tentang

\footnotetext{
${ }^{34}$ Sirajuddin, Legislasi Hukum Islam di Indonesia..., hlm. 155-156.

${ }^{35}$ Fatwa Mejelis Ulama Indonesia (MUI) tentang Wakaf Uang, tanggal 28 Safar 1423 H bertepatan dengan tanggal 1 Mei 2002 M.
} 
Wakaf. Bahkan, penyimpangan dalam pengelolaannya dimasukan dalam tindakan pidana (Bab IX) Pasal 67 ayat (1), (2), dan (3). Namun demikian dalam penjelasan Pasal 62 ayat (2) dinyatakan tentang pemberlakuan upaya tahkim atau arbitarse. Jika tidak bisa diselesaikan melalui tahkim atau arbitrase, penyimpangan itu diproses melalui pengadilan atau mahkamah syariah.

\section{c. Undang-Undang Nomor 19 Tahun 2008 tentang Surat Berharga Syariah Negara}

Melihat pesatnya perkembangan sukuk di negara-negara lain, serta pengalaman yang terjadi selama ini, terutama dari segi manfaat yang ditimbulkan, pemerintah merasa berkepentingan untuk mengeluarkan regulasi yang dapat mendukung perkembangan sukuk diwujudkan ke dalam bentuk penerbitan Surat Berharga Syariah Negara (SBSN). Tujuan penerbitan SBSN adalah dalam rangka mencari alternatif sumber pembiayaan negara. ${ }^{36}$

Dasar hukum berlakunya SBSN diatur dalam Undang-Undang Nomor 19 Tahun 2008 tentang Surat Berharga Syariah Negara. Undang-undang ini disahkan dan diundangkan di Jakarta pada tanggal 7 Mei 2008 Lembaran Negara Republik Indonesia Tahun 2008 Nomor 70. Tambahan Lembaran Negara Republik Indonesia Nomor 4852.

Menurut Undang-Undang Nomor 19 Tahun 2008 tentang Surat Berharga Syariah Negara, yang dimaksud dengan Surat Berharga Syariah Negara atau sukuk negara adalah surat berharga negara yang diterbitkan berdasarkan prinsip syariah, sebagai bukti bagian penyertaan terhadap asep SBSN, baik dalam mata uang rupiah maupun valuta asing. ${ }^{37}$

Di atas disinggung mengenai istilah sukuk, kata sukuk (صكوك) adalah bentuk plural atau jamak dari kata sakk صك merupakan istilah yang bersumber dari Bahasa Arab yang dapat diartikan sertifikat. Sukuk ini bukan merupakan istilah asing yang baru dalam sejarah Islam. Istilah tersebut sudah dikenal sejak abad pertengahan, di mana umat Islam menggunakannya dalam konteks perdagangan internasional. Sukuk dipergunakan oleh para pedagang pada masa itu sebagai dokumen yang menunjukan kewajiban finansal

36 Burhanuddin S, Hukum Surat Berharga Syariah Negara Dan Pengaturannya (Jakarta: PT RajaGrafindo Persada, 2011), hlm. 3.

${ }^{37}$ Pasal 1 angka 1 Undang-Undang Nomor 19 Tahun 2008 tentang Surat Berharga Syariah Negara. 
TAHKIM, Jurnal Peradaban dan Hukum Islam. Vol.1 No.2 (0ktober, 2018) | ISSN : $2597-7962$

yang timbul dari usaha perdagangan dan aktivitas komorsial lainnya. Namun sejumlah penulis Barat yang memiliki concern terhadap sejarah Islam dan bangsa Arab menyatakan, bahwa dari kata sakk inilah yang kemudian menjadi akar kata "cheque" dalam bahasa Latin, sebagai suatu istilah yang lazim dipergunakan dalam transaksi dunia perbankan kontemporer. ${ }^{38}$

Undang-Undang tentang Surat Berharga Syariah Negara ini secara garis besar mengatur hal-hal sebagai berikut: ${ }^{39}$

1) Transparansi pengelolaan SBSN dalam kerangka kebijakan fiskal dan kebijakan pengembangan pasar SBSN dengan mengatur lebih lanjut tujuan penerbitannya dan jenis akad yang digunakan;

2) Kewenangan pemerintah untuk menerbitkan SBSN, baik dilakukan secara langsung oleh pemerintah yang didelegasikan kepada menteri, ataupun dilaksanakan melalaui Perusahaan Penerbitan SBSN;

3) Kewenangan pemerintah untuk menggunakan Barang Milik Negara sebagai dasar penerbitan SBSN (underlying asset);

4) Kewenangan pemerintah untuk mendirikan dan menetapkan tugas badan hukum yang akan melaksanakan fungsi sebagai Perusahaan penerbitan SBSN;

5) kewenangan Wali Amanat untuk bertindak mewakili kepentingan Pemegang SBSN;

6) kewenangan pemerintah untuk membayar semua kewajiban yang imbul dari penerbitan SBSN, baik yang diterbitkan secara langsung oleh pemerintah maupun melalui perusahaan Penerbitan SBSN, secara penuh dan tepat waktu sampai berakhirnya kewajiban tersebut; dan

7) landasan hukum bagi pengaturan lebib lanjut atas tata cara dan mekanisme penerbitan SBSN di Pasar Perdana maupun perdahangan SBSN di Pasar Sekunder agar pemodal memperoleh kepastian untuk memiliki dan memperdagangkan SBSN secara mudah dan aman.

\footnotetext{
${ }^{38}$ Nurul Huda dan Mustafa Edwin Nasution, Investasi pada Pasar Modal Syariah (Jakarta: Kencana, 2008), hlm. 136.

${ }^{39}$ Mardani, Hukum Islam Dalam Hukum Positif Indonesia (Jakarta: PT RajaGrafindo Persada, 2018), hlm. 313-314.
} 


\section{d. Undang-Undang Nomor 21 Tahun 2008 Tentang Perbankan Syariah}

Di dalam mengoperasionalkan bank syariah, dasar hukum pertama adalah alQuran dan hadis. Beberapa ayat di dalam al-Quran sebagai dasar operasional bank syariah, antara lain: ayat-ayat yang melarang transaksi riba (Q.S al-Baqarah 275); larangan memakan harta orang lain secara batil (Q.S al-Niasa: 29) serta hadis-hadis Rasulullah yang senada dengan hal itu.

Selain beberapa ayat al-Quran dan hadis, maka berdasarkan hukum positif landasan dalam mengoperasionalkan bank syariah adalah Undang-Undang Nomor 21 Tahun 2008 tentang Perbankan Syariah (sebelum lahir undang-undang ini, landasan operasional bank syariah adalah Undang-Undang Nomor 10 Tahun 1998 tententang Perubahan atas Undang-Undang Nomor 7 Tahun 1992 tentang Perbankan dimana sebatas diakomodirnya Prinsip Syariah dalam operasional bank, yakni di dalam Pasal 21 ayat (3) jo Pasal 1 butir 13). ${ }^{40}$

Latar belakang dikeluarkannya regulasi perbankan syariah ini, yaitu: ${ }^{41}$ (1) dalam rangka mencapai tujuan pembangunan nasional Indonesia berupa terciptanya masyarakat adil dan makmur berdasarkan demokrasi ekonomi, pengembangan sistem ekonomi yang berlandaskan pada nilai keadilan, kebersamaan, pemerataan, dan kemanfaatan yang sesuai dengan prinsip syariah; (2) adanya kebutuhan masyarakat Indonesia akan jasa-jasa perbankan syariah yang semakin meningkat; (3) perbankan syariah memiliki kekhususan dibandingkan dengan perbankan konvensional; (4) pengaturan mengenai perbankan syariah melalui Undang-Undang Nomor 7 Tahun 1992 tentang Perbankan sebagaimana telah diubah dengan Undang-Undang Nomor 10 Tahun 1998 belum spesifik. Untuk itu maka perbankan syariah perlu diatur secara khusus dalam satu undang-undang tersendiri.

Prinsip perbankan syariah merupakan bagian dari ajaran Islam yang berkaitan dengan ekonomi. Salah satu prinsip dalam ekonomi Islam adalah larangan riba dalam berbagai bentuknya, dan menggunakan sistem antara lain berupa prinsip bagi hasil. Dengan prinsip bagi hasil, Bank Syariah dapat mencapai iklim investasi yang sehat dan adil karena semua pihak dapat saling berbagi baik keuntungan maupun potensi risiko

${ }^{40}$ Dewi Nurul Musjtari, Penyelesaian Snegketa dalam Praktik Perbankan Syariah (Yogyakarta: Parama Publishing, 2012), hlm. 14.

${ }^{41}$ Neneng Nurhasanah dan Panji Adam, Hukum Perbankan Syariah: Konsep dan Regulasi (Jakarta: Sinar Grafika, 2017), hlm. 8-9. 
TAHKIM, Jurnal Peradaban dan Hukum Islam. Vol.1 No.2 (0ktober, 2018) | ISSN : $2597-7962$

yang timbul sehingga akan menciptakan posisi yang berimbang antara bank dan nasabahnya. Dalam jangka panjang, hal ini akan mendorong pemerataan ekonomi nasional karena hasil keuntungan tidak hanya dinikmati oleh pemilik modal saja, tetapi juga oleh pengelaola modal.

Adapun dasar pijakan keluarnya Undang-Undang Nomor 21 Tahun 2008 tentang Perbankan Syariah meliputi beberapa peraturan perundang-undangan yang telah ada sebelumnya, yaitu: ${ }^{42}$

1) Pasal 20 dan Pasal 33 Undang-Undang Dasar Negara Republik Indonesia Tahun 1945;

2) Undang-Undang Nomor 7 Tahun 1992 tentang Perbankan (lembarab Negara Republik Indonesia Nomor 3472) sebagaimana telah diubah dengan UndangUndang Nomor 10 Tahun 1998 (Lembaran Negara Republik Indonesia Tahun 1998 Nomor 182, Tambahan Lembaga Negara Republik Indonesia Nomor 3790);

3) Undang-Undang Nomor 23 Tahun 1999 tentang Bank Indonesia (Lembaran Negara Republik Indonesia Tahun 1999 Nomor 66, Tambahan Lembaran Negara Republik Indonesia Nomor 3843) sebagaimana telah diubah dengan Undang-Undang Nomor 3 Tahun 2004 (Lembaran Negara Republik Indonesia Tahun 2004 Nomor 7, Tambahan Lembaran Negara Republik Indonesia Nomor 4357);

4) Undang-Undang Nomor 24 Tahun 2004 tentang Lembaga Penjamin Simpanan (Lembaran Negara Republik Indonesia Tahun 2004 Nomor 96, Tambahan Lembaran Negara Republik Indonesia Nomor 4420);

5) Undang-Undang Nomor 40 Tahun 2007 tentang Perseroan Terbatas (Lembaran Negara Republik Indonesia Tahun 2007 Nomor 106, Tambahan Lembaran Negara Republik Indonesia Nomor 4756).

Dengan demikian maka dalam hal pelaksanaan Undang-Undang Nomor 21 Tahun 2008 tentang Perbankan Syariah dimaksud hendaknya selalu memperhatikan pada UUD 1945, Undang-Undang Nomor 10 Tahun 1998 tentang Perubahan Atas Undang-Undang

${ }^{42}$ Ibid., hlm. 9. 
TAHKIM, Jurnal Peradaban dan Hukum Islam. Vol.1 No.2 (0ktober, 2018) | ISSN : $2597-7962$

Nomor 7 Tahun 1992 tentang Perbankan, Undang-Undang Nomor 3 Tahun 2004 tentang Perubahan Atas Undang-Undang Nomor 23 Tahun 1999 tentang Bank Indonesia, Undang-Undang Nomor 24 Tahun 2004 tentang Lembaga Penjamin Simpanan, dan Undang-Undang Nomor 40 Tahun 2007 tentang Perseroan Terbatas.

\section{SIMPULAN}

Berdasarkan paparan yang telah diuraikan pada pembahasan sebelumnya, maka pada bab ini akan ditarik beberapa kesimpulan sebagai berikut:

1. Komponen sistem hukum terdiri atas 3 unsur, yaitu struktur, substansi dan budaya hukum. Kedudukan hukum ekonomi syariah dalam ketiga sistem hukum tersebut sudah teraplikasikan. Hal ini dapat dilihat dari banyaknya lembaga-lembaga atau pranata-pranata ekonomi yang berbasiskan nilai-nilai syariah. Terdapat beberapa regulasi dibidang hukum ekonomi syariah yang telah dibuat oleh lembaga legislatif yang bersumber dari norma-norma hukum Islam. Selain lembaga serta regulasi, budaya hukum yang hidup di masyarakat khsusunya di Indonesia mengenai kepatuhan terhadap prinsip-prinsip syariah.

2. Dalam kajian hukum Islam, konsep legislasi biasa disebut dengan istilah taqnîn al-A hkâm. Taqnin al-Ahkam berarti mengumpulkan hukum dan kaidah penetapan hukum yang berkaitan dengan masalah hubungan sosial, menyusunnya secara sistematis, serta mengungkapkannya dengan kalimat-kalimat yang tegas, ringkas, dan jelas dalam bentuk bab, pasal, dan atau ayat yang memiliki nomor secara berurutan, kemudian menetapkannya sebagai undang-undang atau peraturan, lantas disahkan oleh pemerintah, sehingga wajib para penegak hukum menerapkannya di tengah masyarakat

3. Dimensi peraturan perundang-undangan telah terintegrasi dalam hukum nasional dalam perspektif hukum yang telah dilegislasi, salah satunya adalah aturan-aturan di bidang hukum ekonomi syariah. Adapun produk-produk regulasi dibidang hukum ekonomi syariah yang bersumber dari noma-norma hukum Islam antara lain adalah sebagai berikut: (1) UU No. 23 Tahun 2011 tentang Pengelolaan Zakat; (2) UU No. 41 Tahun 2004 tentang Wakaf; (3) UU No. 19 Tahun 2008 tentang Surat berharga Syariah Negara; dan (4) UU No. 21 Tahun 2008 tentang Perbankan Syariah. Dalam konteks hukum Indonesia, dengan adanya legislasi 
TAHKIM, Jurnal Peradaban dan Hukum Islam. Vol.1 No.2 (0ktober, 2018) | ISSN : $2597-7962$

pada produk-produk ekonomi syariah sangat membantu dalam melindungi hakhak konsumen, terlebih masyarakat Indonesia mayoritas menganut agama Islam.

\section{DAFTAR PUSTAKA} Presindo.

Abdurahman. (2007). Kompilasi Hukum Islam di Indonesia. Jakarta: Akademika

Adam, P. (2018). Fatwa-Fatwa Ekonomi Syariah: Konsep, Metodologi Dan Implementasinya Pada Lembaga Keuangan Syariah. Jakarta: Amzah.

Brotosusilo, A. (1986). Sistem Hukum Indonesia. Jakarta: Universitas Terbuka.

Duverger, M. (1981). Sosiologi Politik. Jakarta: Gama Media.

Edwin, M. (2012). Filsafat Hukum, refleksi Kritis Terhadap Hukum. Jakarta: PT RajaGrafindo Persada.

Halim, A. (2005). Politik Hukum Islam di Indonesia. Jakarta: Ciputat Press.

Huda, N. dan Mustafa Edwin Nasution. (2008). Investasi pada Pasar Modal Syariah. Jakarta: Kencana.

Anis, I. Al-Mu jam al-Wasîth. (1987). Beirut: Dar al-Ilmiyah.

Imaniyati, N. S dan Panji Adam. (2016). Pengantar Hukum Perbankan Indonesia. Bandung: Refika Aditama.

Bisnis Syariah. Bandung: Refika Aditama.

(2017). Hukum Bisnis: Dilengkapi Dengan Kajian Hukum . (2018). Pengantar Hukum Indonesia. Jakarta: Sinar Grafika.

Suntana, I. Politik Hukum Islam. (2014) Bandung: Pustaka Setia.

Mardani. (2008). Hukum Islam Dalam Hukum Positif Indonesia. Jakarta: PT RajaGrafindo Persada.

Musjtari, D.N. (2012). Penyelesaian Snegketa dalam Praktik Perbankan Syariah . Yogyakarta: Parama Publishing.

Nurhasanah, N. dan Panji Adam. (2017). Hukum Perbankan Syariah: Konsep dan Regulasi. Jakarta: Sinar Grafika.

Praja, J. S. (2011). Teori Hukum dan Aplikasinya. Bandung: Pustaka Setia. 
TAHKIM, Jurnal Peradaban dan Hukum Islam. Vol.1 No.2 (0ktober, 2018) | ISSN : $2597-7962$

S, Burhanudin. (2011). Hukum Surat Berharga Syariah Negara Dan Pengaturannya. Jakarta: PT RajaGrafindo Persada.

Sirajuddin. (2008). Legislasi Hukum Islam di Indonesia. Yogyakarta: Pustaka Pelajar.

Sudarsono. (2004). Pengantar Ilmu Hukum. Jakarta: Rineka Cipta.

Sumitro, W. (2015). Legislasi Hukum Islam Tramsformatif: Reformulasi Konsep Formulasi Syariah dalam Legislasi Hukum Islam di Indonesia. Malang: Setara Press.

Syahuri, T. (2010). Hukum Konstitusi: Proses dan Prosedur Perubahan UUD di Indonesia 1945-2002. Bogor: Ghalia Indonesia.

Umam, K. (2011). Legislasi Fikih Ekonomi dan Penerapannya dalam Produk Perbankan Syariah di Indonesia. Yogyakarta: BPFE.

Zaenudin, J. (2015). Metode Dan Strategi Penerapan Syariat Islam di Indonesia: Memahami Gradualitas Penerapan Syariat di Indonesia Menuju Penerapan Islam Secara Kaffah. Jakarta: MIUMI dengan Pembela Islam Media.

Zarqa, M. (1418 H). Al-Madkhal al-Fiqh al- `Am. Beirut: Dar al-Qalam.

Yasin, M. N. (2018). Politik Hukum Ekonomi Syariah Di Indonesia. Malang: UIN Maliki Press. 